\title{
Growth response and apparent nutrient digestibility of weaner rabbits fed with diets containing bamboo leaf meal \\ ${ }^{1}$ Idowu, O.M.O., ${ }^{1}$ Oso, A.O., ${ }^{1}$ Adeyemi, O.A., ${ }^{1}$ Osho, S.O., ${ }^{1}$ Idowu, O.P. A. and ${ }^{2}$ Ijaiya, A.T.
}

${ }^{1}$ College of Animal Science and Livestock Production, Federal University of Agriculture, P.M B. 2240. Abeokuta, Nigeria. West Africa. Email: idowuomo@funaab.edu.ng. ${ }^{2}$ Department of Animal Production, School of Agriculture and Agricultural Technology, Federal University of Technology, Gidan Kwano Campus, Minna ,Niger State.

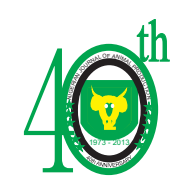

\begin{abstract}
A ten-week feeding trial was conducted to determine the growth response and apparent nutrient digestibility of weaner rabbits fed with diets containing bamboo leaf meal (BLM). Eighty weaner rabbits were allotted into four dietary treatment groups of twenty rabbits each. The dietary treatment groups consisted of four rations containing 0 (control), 10, 20 and 30\% $B L M$ respectively. Rabbits fed diet containing $10 \%$ BLM had the highest $(P<0.05)$ final live weight, weight gain and apparent ether extract digestibility. Lowest $(P<0.05)$ final live weight, weight gain, apparent crude protein and ash digestibility were noticed with rabbits fed with diets containing $20 \%$ or $30 \%$ BLM. Rabbits fed with diet containing $30 \%$ BLM recorded the highest $(P<0.05)$ feed intake and lowest $(P<0.05)$ NDF digestibility. It was concluded that inclusion of $10 \%$ BLM in diets for weaner rabbits supported improved growth and nutrient digestibility.
\end{abstract}

Key words: Bamboo leaf meal, digestibility, performance, rabbit

\section{Introduction}

Rabbit is a promising animal which can be used as alternative meat protein sources due to its rapid growth, higher meat to bone ratio and feed conversion efficiency (Davidson and Spreadbury, 1975). Unlike the chickens which compete with man for cereal grains, rabbits can be sustained on diets low in grains but high in forages, grasses and shrubs due to its ability to digest leaf protein effectively. Bamboo plant (a perennial forage species) is a member of the grass family with over 1200 species available worldwide (Chapman and Peat, 1992). Bambusa arundinaria, a warm temperate genus occurred naturally in Nigeria and holds a lot of potential in livestock feeding. The seeds produced (called 'bamboo rice') are rich in protein
(Invista, 2011) while the leaf holds a lot of potential as feed ingredients in ruminant nutrition. (Devendra, 1992) reported that bamboo leaf hay contained 12.0, 27.0, 0.8 and $18 \%$ crude protein, crude fibre, ether extract and ash, respectively. Bamboo leaf meal (BLM) contained 9.30\% digestible protein, $2150 \mathrm{Kcal} / \mathrm{kg}$ digestible energy and a metabolisable energy content of 1760 $\mathrm{Kcal} / \mathrm{kg}$ (Devendra, 1992). Studies investigating the use of bamboo leaf meal as dietary fibre source in rabbit nutrition are rare. This study therefore, seeks to investigate the growth response and apparent nutrient digestibility of weaner rabbits fed with diets containing bamboo leafmeal. 
Growth response of weaner rabbits fed with diets containing bamboo leaf meal

\section{Materials and methods \\ Preparation and chemical composition of Bambooleaf meal (BLM)}

Bamboo (Bambusa arundinaria) stems were plucked using a sharp knife from the Farm site of College of Plant Science, University of Agriculture Abeokuta, Nigeria. Fresh foliage leaves from the top of the stems were cut, manually separated from the midrib, chopped into smaller pieces (using a sharp knife) and dried (at $60^{\circ} \mathrm{C}$ for $48 \mathrm{hrs}$ ) in a drying chamber. The dried leaves were milled ( $2.5 \mathrm{~mm}$ sieve), bagged and mixed with other feed ingredients to formulate the experimental diets. Representative samples of the bamboo leaf meal (BLM) were analyzed for its proximate composition (AOAC, 1990) (reference identification numbers 924.05, $920.39,984.13)$. For the determination of the fibre fraction, content of NDF was determined without sodium sulfite and with a heat-stable amylase (Van Soest et al., 1991). Acid detergent fibre (ADF) and acid detergent lignin (ADL) were determined by sequential analysis of the residual NDF and not expressed exclusive of residual ash (Van Soest et al., 1991). The hemicellulose was calculated as the difference between NDF and ADF while cellulose was calculated as the difference between ADF and ADL. The gross energy of the samples of BLM was determined using a Gallenkamp Ballistic bomb calorimeter (Cam Metric Ltd, Cambridge, UK). For mineral analysis, dried samples were ashed at $450^{\circ} \mathrm{C}$, and digested in $10 \mathrm{~mL} 1 \mathrm{~mol} / \mathrm{L}$ $\mathrm{HCl}$. Phosphorus content was determined colorimetrically using Molybdo-vanadate method (Kitson and Mellon,1944). Sodium and potassium content were determined in the ash solution by emission spectroscopy at 589.0 and $766.5 \mathrm{~nm}$ respectively, by using an air-acetylene flame. Calcium and magnesium content were measured in the ash solution by atomic absorption spectroscopy (Techtron model AA-10) at 422.7 and $285.2 \mathrm{~nm}$ respectively. For magnesium determination, a strontium chloride solution was added with the aim of avoiding chemical interferences (OJEC, 1973.). Iron and manganese were determined by atomic absorption spectroscopy using single element hollow cathode lamps and air-acetylene flame at 248.3 and $279.5 \mathrm{~nm}$, respectively (AOAC, 1990). Total tannin content was determined colorimetrically as described by AOAC(1990).

Experimental animals, design and management

Eighty, male, six weeks old mixed-bred rabbits (weaned at five weeks) with a mean body weight of $446 \pm 1.65 \mathrm{~g}$ were used for the study. The rabbits were randomly allotted into four dietary treatment groups of 20 rabbits each. Rabbits were housed individually in hutches $(240 \mathrm{~cm} \times 75 \mathrm{~cm} \times$ $75 \mathrm{~cm}(\mathrm{LWH}))$. Each hutch has four cage units and each unit (with a dimension of 60 $\mathrm{cm} \times 75 \mathrm{~cm} \times 75 \mathrm{~cm}(\mathrm{LWH}))$ housed a rabbit. Five of such hutches were used per treatment. The cages were thoroughly cleaned and disinfected two weeks before the arrival of the rabbits. The front side of the hutch was made of wire mesh to allow for aeration while the base made of strong wire netting to allow easy passage of the droppings. Four experimental diets were formulated such that BLM was included at 0 (control), $10 \%, 20 \%$ and $30 \%$ inclusion levels, respectively. Diets were formulated to meet the nutrient requirements of rabbits as stated by (De Blas and Mateos, 1998). Strict hygiene was maintained during the experimental period. Rabbits assigned to each treatment were fed with their respective diets. The feeds were fed ground. Rabbits were fed without restriction with experimental diets while clean water was 


\section{Idowu, Oso,Adeyemi, Osho, Idowu, and Ijaiya}

offered on daily basis throughout the expiration of the study. The composition of experimental diets is as shown in Table 1. The feeding trials lasted for 70 days. Uneaten feed was weighed on a daily basis and discarded. Feeders and drinkers were cleaned every morning after which fresh feed and clean water were offered.

\section{Growth response and nutrient digestibility}

Weight gained and feed intake was determined weekly. Feed conversion ratio was calculated as a ratio of feed consumed to weight gained. At the expiration of the feeding trial (70 days), 8 rabbits per dietary treatment were randomly selected and housed in individual wire metabolism cages (each measuring $400 \times 500 \times 400 \mathrm{~mm}$ ). Prior to the commencement of the trial, rabbits were acclimatized for three days in the metabolic cages followed by four days collection period. The rabbits were fed daily with known weights of feed (which match their daily intake). The faeces (free of feed and visible hair contaminants) were collected daily from each cage and dried overnight at $60^{\circ} \mathrm{C}$. The dried faecal droppings were stored at $-20^{\circ} \mathrm{C}$ before analysis. Prior to analysis, faeces collected were freezed dried and ground ( $2 \mathrm{~mm}$ wire mesh). Refusals and samples of the feeds offered to the animals (during metabolic trial) were collected at the end of the faecal collection period. Pooled samples of refusals, feed and dried faecal samples were used for proximate analysis according to the procedures of Official Methods of Association of Analytical Chemists (AOAC, 1990). The faecal and feed samples were analyzed for ash (method no. 924.05), ether extract (method no. 920.39) and crude protein (total nitrogen $\times 6.25$; method no. 984.13) according to the procedures of Official Methods of Association of Analytical Chemists
(AOAC, 1990). Gross energy values of the samples were determined using the bomb calorimeter. Fibre fractions of the samples were determined without sodium sulfite and with a heat-stable amylase as previously described (Van Soest et al., 1991).

\section{Statistical Analysis}

Data generated during the study were arranged in a completely randomized design and analyzed using one way analysis of variance. Analysis was done using the SAS Computer Package (SAS Institute, 1992). Differences between significant mean values were separated using the Duncan's Multiple Range Test (Duncan, 1955)

\section{Table 1. Determined Chemical composition}

of Bamboo leaf meal (BLM)

\begin{tabular}{ll}
\hline \multicolumn{1}{c}{ Parameters } & Composition values \\
\hline Proximate composition (\%) & 76.00 \\
Dry matter & 12.00 \\
Crude Protein & 29.40 \\
Nitrogen free extract & 29.00 \\
Crude Fibre & 20.00 \\
Ash & 9.42 \\
Gross energy (MJ/kg) & 4.21 \\
aDigestible energy (MJ/kg) & \\
Fibre Fraction (\%) & 52.91 \\
Neutral detergent fibre & 35.10 \\
Acid detergent fibre & 10.10 \\
Acid detergent lignin & 17.81 \\
Hemicellulose & 25.00 \\
Cellulose & \\
Mineral profile (\%) & 0.88 \\
Ca & 0.32 \\
P & 0.68 \\
$\mathrm{Mg}$ & 0.03 \\
$\mathrm{Na}$ & 1.00 \\
$\mathrm{~K}$ & 103.00 \\
$\mathrm{Mn}(\mathrm{mg} / \mathrm{kg})$ & 210.00 \\
$\mathrm{Fe} \mathrm{(mg/kg)}$ & 5.00 \\
$\mathrm{Cu}(\mathrm{mg} / \mathrm{kg})$ & 9.00 \\
$\mathrm{Tannin}(\mathrm{g} / \mathrm{kg})$ & \\
&
\end{tabular}




\section{Results and Discussion}

Composition of Bamboo leafmeal

The determined proximate composition of Bamboo leaf meal (BLM) as presented in Table 1 revealed a high dry matter content, moderately low crude protein and low gross energy content. The low gross and estimated digestible energy content were indicative of the limitations involved in the use of BLM as dietary energy sources in rabbit nutrition. The high dry matter obtained could be due to the period of leaf collection (within the peak of dry season). The high crude fibre and low protein content assayed for BLM suggested it as a potential fibrous low protein source in rabbit nutrition. Rabbits have the potentials to utilize efficiently fibrous feedstuffs and forages (Garcia et al.,1996). The crude protein value of BLM was closer to values reported for some leaves obtained from trees of fodder and browse plants commonly consumed by rabbits and other ruminant animal (Khanal et al., 1999).

The mineral profile of BLM showed a high $\mathrm{Ca}, \mathrm{Mg}, \mathrm{K}$ and moderate $\mathrm{P}$ content. The high $\mathrm{Ca}$ and $\mathrm{P}$ content of BLM implied that it contained essential minerals needed for bone development in rabbits. The $\mathrm{P}$ content of BLM was close to $0.37 \%$ while the $\mathrm{Ca}$ content was higher than $0.22 \%$ being $\mathrm{P}$ and $\mathrm{Ca}$ values, respectively recommended by (Chapin, and Smith, 1967) for growing rabbits. The $\mathrm{Mg}$ and $\mathrm{K}$ content were higher than the values of $30-40 \mathrm{mg} / 100 \mathrm{~g}$ and $0.6 \%$

Table 2. Gross composition (\%) of the experimental concentrate diets

\begin{tabular}{|c|c|c|c|c|}
\hline \multirow[b]{2}{*}{ Ingredients } & \multicolumn{4}{|c|}{ Level of inclusion of BLM (\%) } \\
\hline & 0 & 10 & 20 & 30 \\
\hline Maize & 44.00 & 35.20 & 27.10 & 21.30 \\
\hline Soybean meal & 18.00 & 16.80 & 14.90 & 12.70 \\
\hline Bamboo leaf meal & - & 10.00 & 20.00 & 30.00 \\
\hline Fish meal ( $72 \%$ Crude Protein) & 1.00 & 1.00 & 1.00 & 1.00 \\
\hline Brewers dried grain & 30.00 & 30.00 & 30.00 & 30.00 \\
\hline Rice husk & 3.50 & 3.50 & 3.50 & 3.50 \\
\hline Oyster shell & 1.00 & 1.00 & 1.00 & 1.00 \\
\hline Bone meal & 2.00 & 2.00 & 2.00 & 2.00 \\
\hline${ }^{\mathrm{a}}$ Vitamin/Mineral premix & 0.25 & 0.25 & 0.25 & 0.25 \\
\hline Salt & 0.25 & 0.25 & 0.25 & 0.25 \\
\hline Total & 100.00 & 100.00 & 100.00 & 100.00 \\
\hline \multicolumn{5}{|l|}{ Determined Analysis } \\
\hline Dry matter (\%) & 89.56 & 90.00 & 90.13 & 90.60 \\
\hline Gross energy $(\mathrm{MJ} / \mathrm{kg})$ & 17.38 & 16.60 & 15.97 & 15.21 \\
\hline Crude protein $(\%)$ & 18.84 & 17.97 & 16.91 & 15.62 \\
\hline Crude fibre (\%) & 15.12 & 17.52 & 19.01 & 21.12 \\
\hline Ether extract (\%) & 1.13 & 1.44 & 1.56 & 1.73 \\
\hline NDF (\%) & 30.40 & 31.70 & 32.02 & 34.42 \\
\hline ADF (\%) & 17.90 & 18.02 & 18.79 & 18.97 \\
\hline ADL $(\%)$ & 3.40 & 3.63 & 3.80 & 3.98 \\
\hline
\end{tabular}


values being $\mathrm{Mg}$ and $\mathrm{K}$ levels recommended, respectively for growing rabbits. The $\mathrm{Cu}$ content of BLM was higher than the dietary level of $3 \mathrm{mg} / \mathrm{kg}$ suggested by (Smith and Ellis, 1947) for growing rabbits. The Mn content was far higher than dietary level of $2.5-8.5 \mathrm{mg} / \mathrm{kg}$ reported by (Smith and Ellis, 1947) to show deficiency symptoms in growing rabbits. The fibre fraction analysis of BLM showed that it contained a high NDF, ADF, ADL and cellulose content. The NDF and ADF fraction was higher than $33-40 \%$ NDF (9) and 17\% ADF (García et al., 1999) being values recommended for growing rabbits. The high lignin content of BLM could be implicative of low mineral intake by animals (McDowell and Conrad, 1990). Value of tannin reported for BLM in this study was low and may not be considered to have negative effect on the feed utilization and performance of rabbits. Although, lignin and tannin have been reported as the most anti-nutrients present in leaves of trees commonly consumed by animals (Khanal etal., 1999).

\section{Growth performance and apparent nutrient digestibility}

Growth performance and apparent nutrient digestibility of rabbits fed with diets containing BLM is as shown in Table 3. Low $(\mathrm{P}<0.05)$ final liveweight, weight gain, apparent crude protein and ash digestibility were recorded with rabbits fed with diets containing 20 and 30\% BLM. The low apparent crude protein and ash digestibility recorded for rabbits fed with 20 and $30 \%$ BLM could be linked with increased dietary fibre (as BLM inclusion increased) which reduced nutrient absorption and utilization (Champe and Maurice, 1983 and Cheeke et al., 1986). Such increased dietary fibre have been reported to modified the concentration of caecal VFA, reduce nutrient digestibility ( Longe and Adetola, 1983) and affect energy and nutrient balance ( Noblet and Le Goff, 2001). Although, feed intake appreciated with increasing dietary inclusion of BLM, rabbits fed diets containing 30\% BLM had the worst $(\mathrm{P}<0.05)$ feed to gain ratio, apparent ether extract and NDF digestibility. Highest $(\mathrm{P}<0.05)$ apparent crude protein and ash digestibility were recorded with control fed rabbits while those fed with diet containing 10\% BLM had the highest $(\mathrm{P}<0.05)$ final liveweight, weight gain and apparent ether extract digestibility. Beyond 10\% BLM inclusion level, weight gain and final liveweight

Table 3: Growth response and apparent nutrient digestibility of rabbits fed diet containing bamboo leaf meal

\begin{tabular}{|c|c|c|c|c|}
\hline \multirow[b]{2}{*}{ Measurements } & \multicolumn{4}{|c|}{ Level of inclusion of Bamboo leaf meal (\%) } \\
\hline & 0 & 10 & 20 & 30 \\
\hline Litter number & 20 & 20 & 20 & 20 \\
\hline Initial weight ( $\mathrm{g} / \mathrm{rabbit})$ & $447.23 \pm 16.89$ & $446.00 \pm 15.57$ & $443.90 \pm 16.92$ & $447.77 \pm 16.92$ \\
\hline Final liveweight (g/rabbit) & $1381 \pm \overline{7} 1.28^{\mathrm{b}}$ & $1409.87 \pm 86.83^{\mathrm{a}}$ & $1317.50 \pm 175.15^{\mathrm{c}}$ & $1325 \pm \overline{3} 6.32^{\mathrm{c}}$ \\
\hline Weight gain (g/rabbit) & $934.5 \overline{3} \pm 96.23^{\mathrm{b}}$ & $963.87+142.76^{\mathrm{a}}$ & $873.60 \pm 157.70^{\mathrm{c}}$ & $877.5 \overline{7}+116.80^{\mathrm{c}}$ \\
\hline Total feed intake (g/rabbit) & $4499.47 \pm 205.11^{\mathrm{c}}$ & $4466.67 \pm 196.35^{\mathrm{b}}$ & $4494.97 \pm 327.61^{\mathrm{b}}$ & $5732.90 \pm 462.66^{\mathrm{a}}$ \\
\hline Feed conversion ratio & $4.39 \pm 0 . \overline{8} 8^{\mathrm{b}}$ & $4.63 \pm 0 . \overline{7} 4^{\mathrm{b}}$ & $5.15 \pm 0.83^{\mathrm{ab}}$ & $6.53 \pm 1.01^{\mathrm{a}}$ \\
\hline \multicolumn{5}{|l|}{ Apparent nutrient digestibility } \\
\hline Dry matter $(\%)$ & $75.57 \pm 1.90$ & $71.90 \pm 4.06$ & $70.26 \pm 5.94$ & $69.03 \pm 3.70$ \\
\hline Crude protein $(\%)$ & $85.83 \pm 1.19^{\mathrm{a}}$ & $81.86 \pm 2.62^{b}$ & $65.35 \pm 2.49^{c}$ & $64.39 \pm 4.51^{\mathrm{c}}$ \\
\hline Ether extract $(\%)$ & $74.26 \pm 2.00^{\mathrm{b}}$ & $83.68 \pm 2.36^{\mathrm{a}}$ & $73.70 \pm 4.45^{\mathrm{b}}$ & $66.94 \pm 3.34^{\mathrm{c}}$ \\
\hline Ash (\%) & $81.51 \pm 0.66^{\mathrm{a}}$ & $77.97 \pm 1.97^{\mathrm{b}}$ & $71.31 \pm 1.89^{c}$ & $72.26 \pm 3.12^{\mathrm{c}}$ \\
\hline NDF $(\%)$ & $49.11 \pm 1.11^{\mathrm{a}}$ & $48.50 \pm 1.02^{\mathrm{a}}$ & $49.00 \pm 2.01^{\mathrm{a}}$ & $45.20 \pm 1.04^{\mathrm{b}}$ \\
\hline $\operatorname{ADF}(\%)$ & $42.10 \pm 1.09$ & $42.22 \pm 1.04$ & $41.97 \pm 1.62$ & $42.00 \pm 2.01$ \\
\hline ADL $(\%)$ & $44.10 \pm 1.99$ & $43.97 \pm 1.42$ & $44.13 \pm 1.20$ & $44.21 \pm 2.08$ \\
\hline
\end{tabular}


reduced $(\mathrm{P}<0.05)$ significantly. This could be attributed to the increasing lignin content of the diet as BLM inclusion level increased resulting in reduced nutrient utilization (Wiseman, 1987). Increased dietary lignin content resulted in short transient retention period of caecal digesta, hence low nutrient digestion and utilization. The mean retention time of caecal digesta in rabbits was reported to increase from 14 to 21 hours when the dietary fibre is lowered (Gidenne, 1994).

The linear increase in feed intake as dietary inclusion of BLM increased could be due to the decline in resultant energy content of the diets (with increased BLM inclusion). Rabbit is able to adjust its digestible energy (DE) intake to meet requirement hence increased dietary fibre resulted in a proportional increase in the voluntary feed intake ( Gidenne, 1995). Although, in cases of excess dietary fibre intake, energy intake and performance is seriously compromised (Chao and Li, 2007). Fibre has been reported as a major component in rabbit nutrition (Villamide and Fraga, 1998), hence rations fed to intensively reared rabbits should contain the minimum content of fibre required to prevent digestive disorders (Maertens, 1992). Depending on the dietary composition of the fibre source, increased dietary fibre levels have been reported to cause increased (Champe and Maurice, 1983) or decreased (De Blas et al., 1986 and Maître et al., 1990) growth response in rabbits.

It was concluded that inclusion of $10 \%$ BLM in diets for weaner rabbits supported improved growth and nutrient digestibility.

\section{Reference}

AOAC, 1990. Association of Official Analytical Chemists, Official methods of analysis, $15^{\text {th }}$ edition. Washington D.C.
Champe, R.A. and Maurice, D.V., 1983. Research review on response of earlyweaned rabbit to source and level of dietary fibre. J. Appl. Rabbit Res. 6 (2), 64-67.

Chao, H.Y. and Li, F.C., 2007. Effect of level of fibre on performance and digestion traits in growing rabbits. Anim. Feed Sci. Tech. 144, 279-291

Chapin, R.E. and Smith, S.E., 1967. Calcium requirement of growing rabbits. Journal of Animal Science 26(2), 67-77.

Chapman, G.P. and Peat, W.E. 1992. An introduction to grasses (including bamboos and cereals). Pp 118._CAB International, Oxford.

Cheeke, P.R., Grobner., M.A. and Patton., N.M. 1986. Fibre digestion and utilization in rabbits. J. Appl. Rabbit Res. 9(1), 25 - 30

Davidson J. and Spreadbury, D. 1975. Nutrition of the New Zealand white rabbits. Proceeding of the British Nutrition Society. 34: 75-83.

De Blas J.C. and Mateos G.G. 1998. Feed Formulation. In: De Blas C., Wiseman $J$. (Eds). The Nutrition of the Rabbit. CABI Publishing. CAB International, Wallingford Oxon, UK, 241-253.

De Blas J.C., Santomá G., Carabaño R.and Fraga, M.J., 1986. Fiber and starch levels in fattening rabbit diets. J. Anim. Sci. 63, 1897-1904.

Devendra, C., 1992. Non conventional feed resources in Asia and the pacific. ( $4^{\text {th }}$ Edtn) RAPA/APHA Publication . No. 40, FAO Regional Office, Bangkok, Thailand, P. 170

Duncan, D.B., 1955. New Multiple Range and Multiple F test. Biometrics, 11, 142

García J., Carabaño R., de Blas J.C., 1999. Effect of fiber source on cell wall digestibility and rate of pasaje in 
rabbits. J. Anim. Sci. 77, 898-905

Garcia, J., R. Caraban, L., Pe'rez-Alba., J. C. de Blas., 1996. Effect of type of fibre on NDF digestion and caecal traits in rabbits. In: F. Lebas (ed.), Proceedings of the 6th World Rabbit Congress. Vol 6, INRA, Toulouse. pp 175-180.

Gidenne, T., 1994. Effets d'une reduction de la teneur en fibres alimentaires sur le transit digestif du lapin. Comparaison et validation de mod\&es d'ajustement des cinetiques d'excretion f\&ale des marqueurs. Repr. Nutr. Develop., 34, 295-306.

Gidenne, T., 1995. Effect of fibre level reduction and gluco-oligosaccharide addition on the growth performance and ceacal fermentation in the growing rabbits. Anim. Feed Sci. Tech. 56, 253-263.

Invista, 2011. Bamboo description. In vwww.innvista.com/health/food/vege table/ bamboo.htm

Khanal, R.C., Panday, S.B., Khanal, S.K., 1999. Nutrient content in the fodder trees and shrubs found in various parts of Nepal. Proceedings of the $1^{\text {st }}$ convention of the Society of Agricultural Scientists, Nepal, 9-11 ${ }^{\text {th }}$ June, Kathmandu, Nepal.

Kitson, R. E. and Mellon, M.G., 1944. Colorimetric determination of $\mathrm{p} \mathrm{hos} \mathrm{phor} \mathrm{u} \mathrm{s} \mathrm{a} \mathrm{s}$ molybdivanadophosphoric acid. Ind. Eng. Chem. Anal. Educ. 16,369-383.

Longe, O.G. and Adetola, J.A., 1983. Metabolizable energy value of some agricultural waste and industrial byproduct for layers. J. Anim. Prod. Res. $3,1-3$.

Maertens, L., 1992. Rabbit nutrition and feeding: A review of some recent developments. J. Appl. Rabbit Res. 15, 889-892.
Maître, I., Lebas, F., Arveux, P., Bourdillon, A., Duperray, J. and Saint Cast, Y., 1990. Taux de lignocellulose (ADF de Van Soest) et performances de croissance du lapin de chair. In: 5ème J. Rech. Cunicoles Fr., 12-13 December, Paris, ITAVI, Paris, pp. 561-5611.

Mc Dowell, L.R. and Conrad, J.H., 1990. Mineral imbalances of grazing livestock in Tropical countries. Int. J. Anim. Sci. 5, 21-32.

Noblet, J. and Le Goff, J., 2001. Effect of dietary fibre on energy value of feeds for pigs. Anim. Feed Sci. Tech.90,3552

Official Journal of European Communities (OJEC), 1973. Directive 73/46/EEC of 5 December. Official Journal of the European Communities 30/03/1973. Brussels.

SAS Institute, 1992. SAS, STAT software: changes and enhancements, release 6.07. SAS Technical Report P. 229. Cary. NC.

Smith, S.E. and Ellis, G.H. 1947. Studies of the Manganese requirement of rabbits. J. Nutri. 34: 33-41

Van Soest, P.J., Robertson, J.B.and Lewis, B.A., 1991. Methods for dietary, fiber, NDF and non- starch polysaccharides in relation to animal nutrition. J. Dairy Sci. 74, 3583-3597.

Villamide, M.J.and Fraga, M.J., 1998. Predictions of digestive crude protein and protein digestibility of feed ingredients for rabbite from chemical analysis. Anim. Feed Sci. Tech. 70, 211-224.

Wiseman, J. 1987. Feeding of Non Ruminant Livestock. Butterworths, London.

Received: 22/07/12 Accepted: 15/09/13 